\author{
Katarzyna Szorc \\ Uniwersytet w Białymstoku \\ E-MAIL: k.szorc@uwb.edu.pl
}

\title{
O irytacji bez irytacji
}

\section{STRESZCZENIE}

Emocje o różnych znakach - pozytywnych i negatywnych - nie są wcale czymś dziwnym czy nieprawidłowym, wręcz przeciwnie - są ważne i potrzebne w naszym życiu. Co więcej, każdego dnia doświadczamy emocji, pod wpływem których podejmujemy takie czy inne decyzje, postępujemy w taki czy inny sposób. W artykule podjęto próbę analizy kategorii „irytacja”. Irytacja jest emocją o wyjątkowym znaczeniu społecznym, stąd rozważania przedstawione w tekście odwołują się do dorobku nauk społecznych (psychologicznych, socjologicznych).Prezentowany tekst ma charakter przeglądowy. Przedstawiono podstawowe ujęcia klasyfikacji emocji funkcjonujące w literaturze, a na tym tle usytuowano emocję irytacji (częściej określaną jako złość lub gniew). Ukazano też przyczyny oraz mechanizmy powstawania irytacji. Zwrócono również uwagę na przebieg tej emocji oraz jej społeczne funkcje.

SŁOWA KLUCZOWE: irytacja, złość, gniew, mechanizmy powstawania złości, społeczne funkcje złości.

Ludzie doświadczają i używają szerokiej gamy emocji, które mobilizuja ich i każa reagować w określony sposób na siebie oraz na sytuacje. Złość na przykład każe jednostkom być agresywnymi wobec innych $w$ danej sytuacji, natomiast szczęście prowadzi do tego, że ludzie budują więzi z innymi.

(Turner, Stets, 2009, s. 25)

Czy można działać bez emocji, czy można żyć bez emocji... Czy można pisać o irytacji bez irytacji? Jeśli poddam się irytacji i w złości napiszę tekst, okaże się, że mój sposób wyrażania emocji jest niewłaściwy. Okazywanie emocji nie jest społecznie akceptowane, jest raczej niestosowne. $Z$ reguły ludzie uważają, że ujawnianie swoich emocji jest czymś złym, a zatem nawet wtedy, gdy je przeżywamy, trzeba je dobrze „ukryć” (por. Mayer i Salovey, 1999). Tymczasem warto mieć świadomość, że emocje - zarówno te o pozytywnym znaku (radość, zdziwienie), jak i ujemnym (strach, gniew) - nie są wcale czymś dziwnym czy nieprawidłowym, wręcz przeciwnie - są ważne i potrzebne w naszym życiu. Warto przy tym zauważyć, że każdego 
dnia doświadczamy emocji, pod wpływem których podejmujemy takie czy inne decyzje, postępujemy w taki czy inny sposób.

Badaczka reguł odczuwania emocji i pracy nad nimi, Arlie R. Hoschild, zauważa, że na co dzień ludzie są bardzo uporządkowani emocjonalnie (Hoschild, 2012). Są radośni na weselach, smutni na pogrzebach. Natomiast dość rzadko umiemy zapanować nad emocjami (lub tłumimy emocje) w miejscu pracy lub w sytuacjach wymykających się z określonej konwencji (Goffman, 2008).

Prezentowany artykuł ma charakter przeglądowy. Irytacja jest emocją o wyjątkowym znaczeniu społecznym, stąd rozważania przedstawione w tekście odwołują się do dorobku nauk społecznych (psychologicznych, socjologicznych). W tekście dokonuję charakterystyki irytacji jako emocji sytuując ją na tle najczęściej przedstawianych w literaturze przedmiotu klasyfikacji, modeli. W dalszej części przedstawię funkcje, jakie pełni ta emocja, oraz zarysuję możliwe powody jej odczuwania.

\section{Irytacja znaczy...}

...nie sposób jednoznacznie dokończyć rozpoczętego w nagłówku zdania. $\mathrm{W}$ jednym $\mathrm{z}$ artykułów psychologicznych ostatnich lat czytam:

Można odnieść wrażenie, że psychologia dysponuje znacznie uboższą wiedzą o emocjach niż przeciętny obywatel, a wiedza ta jest znacząco mniej trafna niż wiedza wielu humanistów (Jarymowicz, Imbir, 2010, s. 439).

Skoro wiedza o emocjach jest wciąż niewystarczająca, również wiedza i możliwość samego zdefiniowania kategorii „irytacja” nie jest łatwa. Zgodnie ze SŁOWNIKIEM J̨̨ZYKa POLSKIEGO „irytacja” oznacza "gniewne podniecenie, rozdrażnienie, denerwowanie się" (Szymczak, 1978, s. 808). Jak tę emocję definiuje psychologia?

Irytacja ${ }^{1}$, złość i gniew często są wzajemnie nieodróżniane, a w literaturze anglojęzycznej określane zwykle jednym terminem „anger”. Emocje te są natomiast współcześnie jednymi z najczęściej badanych, przynajmniej w badaniach anglojęzycznych.

Analiza literatury przedmiotu pozwala stwierdzić, iż „irytacja” bardzo rzadko jest bezpośrednio opisywana jako emocja. Ślad opisywanej kategorii można odnaleźć jedynie w koncepcji Schlosberga. Autor zaproponował model afektu na podstawie materiału werbalnego poprzez przymiotniki opi-

Dla potrzeb niniejszego tekstu kategorie: „irytacja”, „złość”, „gniew” będą używane zamiennie. 


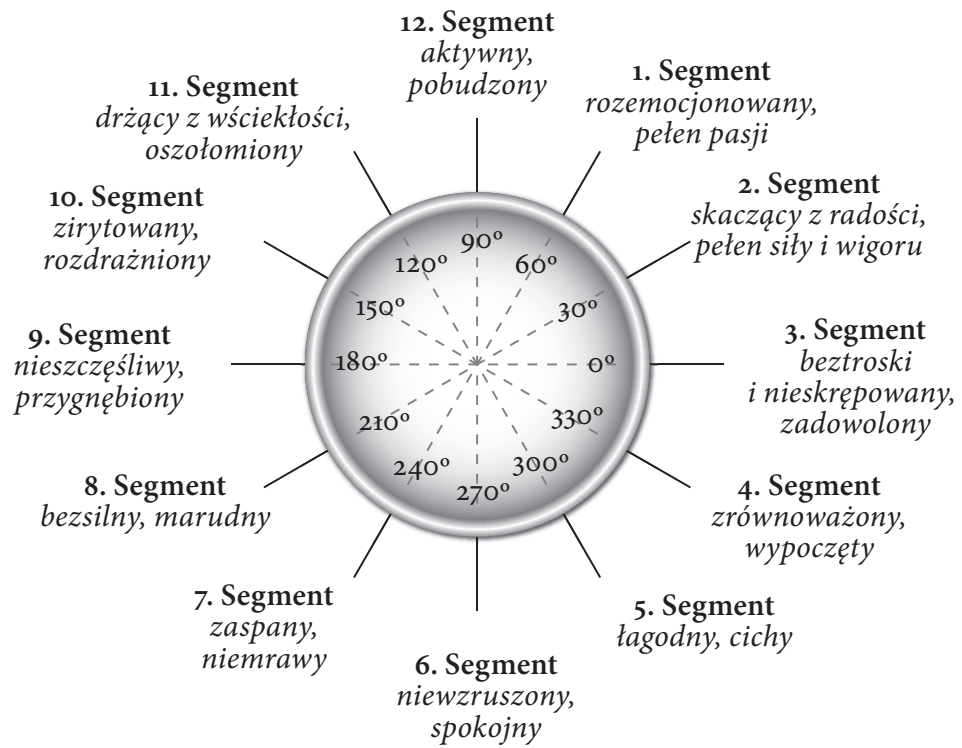

\section{Rys. 1. Kołowy model afektu}

Źródło: (za: Yik, 2009, s. 417)

sujące emocje. Model sytuuje emocje w ten sposób, że im znajdują się bliżej siebie, tym związek między nimi jest silniejszy. Emocje znajdujące się zaś na przeciwległych krańcach okręgu są względem siebie przeciwstawne. Koncepcję Schlosberga Z 1952 roku zmodyfikował najpierw Russell (1980), który umiejscowił afekty na dwuwymiarowej przestrzeni, przypominającej kompas. Wymiar wschód-zachód odpowiada walencji afektu: przyjemność-niezadowolenie. Natomiast wymiar północ-południe odpowiada wymiarowi pobudzenie-senność.

Model Russella w swoich badaniach wykorzystała w kolejnych latach Yik (2009), której koncepcja zawiera 12 segmentów rozmieszczonych na planie tarczy zegara: 12 - aktywacja, 6 - dezaktywacja, 9 - niezadowolenie, 3 przyjemność. Zgodnie z tym ujęciem przymiotnik „zirytowany” jest najbardziej powiązany z „rozdrażniony”, „drżący z wściekłości”, „oszołomiony” i „nieszczęśliwy”, „przygnębiony”.

Kołowy model afektu zakłada również, że nie ma ostrych granic pomiędzy stanami emocjonalnymi. Zdarza się tak, że jedna emocja niepostrzeżenie przechodzi w drugą lub też trudno jest jednoznacznie określić, czy stan jest związany ze zirytowaniem, czy to już jest wściekłość. Russel porównał ten model do koła kolorów, gdzie, co prawda, jesteśmy w stanie zidentyfi- 


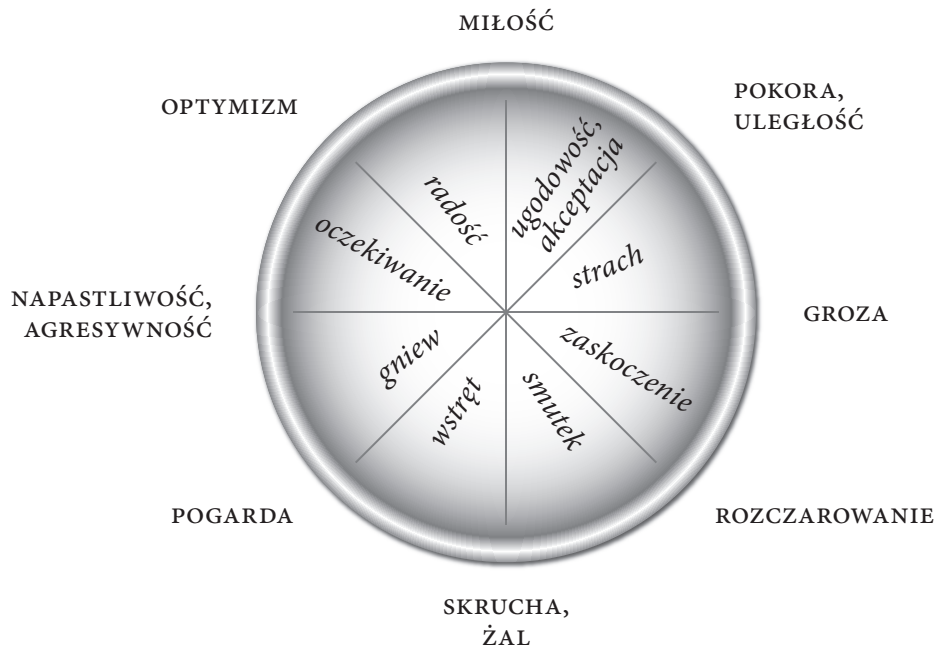

\section{Rys. 2. Kołowy model emocji pierwotnych według Roberta Plutchika}

Źródło: (za: Jarymowicz, Imbir, 2010 s. 442)

kować poszczególne barwy (zieleń, niebieski, czerwień), jednak można też dostrzec, że jedna barwa w sposób łagodny stopniowo łączy się z drugą (Russell, 1989). Można zatem przyjąć, że - w zależności od intensywności emocji - pisząc czy mówiąc o irytacji mamy na uwadze po trosze rozdrażnienie albo też wściekłość. Warto dodać, że model koła afektu ma szerokie zastosowanie w psychologii i został potwierdzony w próbach badawczych z różnych kultur, posługujących się różnymi językami (angielskim, hiszpańskim, chińskim, japońskim, koreańskim, estońskim, greckim, polskim (za: Stanisławski, 2014).

Jedną z ważniejszych koncepcji emocji opracował również Paul Ekman, u którego gniew traktowany jest jako emocja podstawowa. Autor zakłada również, że:

wszystkie emocje są podstawowe w tym sensie, że zarówno specyficzne cechy emocji, jak i ich cechy podzielane $\mathrm{z}$ innymi emocjami oraz funkcje ukształtowane zostały przez ewolucję. Wskazuje na osiem cech, z których przynajmniej siedem odnaleźć można we wszystkich emocjach (z wyjątkiem specyficznego sygnału) (Ekman, 1999, s. 49).

Ekman proponuje także, aby wprowadzić pojęcie „rodziny emocji”, tak „by każdą emocję uważać za rodzinę pokrewnych stanów afektywnych, nie zaś za pojedynczy stan" (Ekman, 1999, s. 49). Autor interesująco odnosi się do 
irytacji, traktując ją jako emocję, która może być pochodną emocji gniewu (lub gniewu o małej intensywności), albo jako nastrój, który wzbudza uczucie gniewu. Wprawdzie w psychologii różnicuje się pojęcia emocji i nastrojów, jednakże oba terminy należą do zjawisk afektywnych (Davidson, 1999, s. 50).

W postaci koła - podobnie jak przywołany już w tekście model Yik - emocje przedstawia Robert Plutchik, twórca psychoewolucyjnej koncepcji emocji.

Autorowi nie chodziło tylko o wymienienie emocji, ponieważ główną intencją było zestawienie ich wcztery diady. Diada rozumiana jest jako para emocji „przeciwstawnych”, przy czym wzbudzenie jednej, uniemożliwia wzbudzenie drugiej w tym samym czasie. Dla przykładu - trudno jest rozbawić kogoś, gdy ten przeżywa smutek. Należy najpierw wygasić emocję smutku, a potem dążyć do wzbudzenia emocji radości.

Według Plutchika

(...) ósemka zróżnicowanych jakościowo emocji to podstawowe afekty, z których połączenia powstają rozmaite nowe jakości: „emocje mieszane” (na podobieństwo podstawowych barw, z których zmieszania można uzyskać ogromną paletę kolorów). Plutchik umieścił obok siebie emocje, które łączą się stosunkowo najłatwiej. Tworzą one diady II stopnia. Według jego propozycji, z powiązania zaskoczenia i smutku powstaje rozczarowanie; z zaskoczenia i strachu - poczucie uniżenia; ze strachu i lubienia - poczucie poddania się; z oczekiwania czegoś i radości - nadzieja; z oczekiwania czegoś i złości - gniew (wściekłość, furia); z radości i lubienia - miłość; ze złości i wstrętu - pogarda; ze wstrętu i smutku - wyrzuty sumienia (Jarymowicz, Imbir, 2010, s. 442).

Interesującą, $\mathrm{z}$ perspektywy podjętego $\mathrm{w}$ niniejszym tekście problemu, jest diada emocji „strach vs gniew ”, gdzie „gniew” nazywany jest również jako „złość” lub „irytacja”. Warto podkreślić, że w ujęciu Plutchika „złość” jest emocją pozytywną, ponieważ pełni ona funkcję mobilizowania człowieka do poradzenia sobie z jakąś trudną sytuacją, do zmierzenia się z czymś negatywnym (Plutchik, 1980).

Pomijając spór psychologów o istnienie emocji podstawowych i wtórnych, można zauważyć, że „irytacja” (gniew, złość) pojawia się jako ważna w większości koncepcji i modeli. Kłopotem może być jednak ustalenie walencji emocji, która jest podstawową kategorią ich opisu. Pomimo iż Robert Plutchik uznaje irytację za emocję pozytywną, to większość badaczy (Lazarus, 1991; Oatley i Jenkins, 2003; Frijda, 1986) sytuuje ją wśród emocji negatywnych, wyjaśniając, że te właśnie są „efektem oceny relacji z otoczeniem jako niezgodnej z tym, czego chce podmiot, czyli niezgodnej z celami podmiotu" (Łosiak, 2007, s. 38). 
Uczucie gniewu jest różnie rozumiane i oceniane w zależności od kultury. Spostrzeżenia na temat kulturowych uwarunkowań gniewu odnajdujemy w pracach Markus i Kitayamy (1994). Autorzy dostrzegają związek różnic kulturowych w postrzeganiu i wyrażaniu gniewu z typem ,ja” dominującym w danej kulturze (z podziałem na „ja” niezależne i współzależne). Dla przykładu - w Stanach Zjednoczonych uczucie złości zwykle związane jest z postrzeganiem przeszkody w osiągnięciu indywidualnych celów człowieka lub ograniczeniem jego praw. W związku z tym gniew nie jest całkowicie niepożądany, ponieważ odpowiada kulturowemu dążeniu do niezależności. Inaczej w Japonii - w tej kulturze pożądane są takie emocje, które towarzyszą współzależności (życzliwość, łagodność). Gniew u Japończyków jest widziany jako uczucie skrajnie negatywne, ponieważ jego okazywanie powoduje zakłócenie lub, w skrajnym wypadku, zerwanie relacji tworzących współzależność (Markus, Kitayama, 1994, s. 101-102).

Złość potocznie jest uważana za emocję negatywną, również z uwagi na potencjalnie szkodliwe, wręcz bolesne skutki społeczne jej wyrażania. Wydaje się jednak, że ujęcie adaptacyjne emocji prowadzi do nieuzasadnionego podziału emocji na pozytywne i negatywne - tak jak to klasycznie w modelach i klasyfikacjach emocji bywa. Zdaniem Żemojtel-Piotrowskiej i Piotrowskiego (2012) o wiele bardziej korzystne jest zastosowanie kryterium zgodności z celem. Emocje tzw. pozytywne, takie jak szczęście czy poczucie dumy, są przykładami emocji zgodnych z celem, natomiast gdy następuje brak zgodności z celem, wówczas pojawiają się emocje uznawane potocznie za negatywne, takie jak strach, smutek czy złość.

Przyjmując, że emocja to „subiektywny stan psychiczny, uruchamiający priorytet dla związanego z nią programu działania, któremu towarzyszą zwykle zmiany somatyczne, ekspresje mimiczne i pantomimiczne oraz specyficzne zachowania" (Strelau i Doliński, 2008; Maruszewski, Doliński, Łukaszewski i Marszał-Wiśniewska, 2008), można stwierdzić, iż irytacja uruchamia program działania czy też ukazuje „relacje o przeżywaniu bardzo silnych tendencji do działania mającego kogoś skrzywdzić czy coś uszkodzić, czyli o jednoznacznie agresywnym charakterze" (Łosiak, 2007, s. 58). Dodać należy, że emocja ta sygnalizuje coś ważnego o relacjach człowieka $z$ otaczającym światem i wpływa na reakcję podmiotu na sytuację (Oatley i Jenkins, 1996). 


\section{Czemu się złościmy, czyli jakie są powody, proces i funkcje odczuwanej złości?}

Poglądy badaczy (psychologów, neurobiologów) na temat mechanizmów powodujących emocje złości (irytacji, gniewu) są zróżnicowane. Przedstawiciele koncepcji poznawczych twierdzą, że dla gniewu ważna jest ocena czegoś niekorzystnego jako wywołanego przez inną osobę (Lazarus, 1991). Jeżeli człowiek za doznany uraz obwinia drugą osobę i przypisuje tym działaniom intencjonalność, wówczas reaguje złością. Zatem nie wystarczy samo doświadczenie zablokowania drogi dojścia do wytyczonego celu, niezbędne jest przypisanie odpowiedzialności za nasz gniew komuś innemu.

Inne stanowisko zakłada, że możemy doświadczać złości bez przypisywania drugiemu odpowiedzialności za wywołanie tej emocji. Stein i Levine twierdzą, że „ocena złych intencji w otoczeniu nie jest konieczna, a frustracja jest wystarczającym warunkiem wystąpienia gniewu" (za: Łosiak, 2007, s. 59). Podobnie przyczyny powstawania złości wyjaśnia Berkovitz, który „zwrócił uwagę, że gniew jest typową, bezpośrednią reakcją na silny ból, a jakiekolwiek bodźce zewnętrzne, skojarzone z doświadczeniami wywołującymi gniew, są w stanie wywołać tę emocję prawie automatycznie" (Łosiak, 2007, s. 59).

Pomimo dyskusji, czy złość stanowi emocję podstawową, w jaki sposób wywoływana jest ta emocja, jakie mechanizmy ją powodują, bez wątpienia pozostaje fakt, że złość pełni wiele funkcji. Ponieważ społeczne skutki wyrażania gniewu mogą być szkodliwe, oraz to, że może on wiązać się z agresją, emocję tę uznaje się za negatywną i, tym samym, jest często podejmowana w badaniach nad regulacją zachowań interpersonalnych. Człowiek, który ma problemy z regulowaniem oraz właściwym wyrażaniem irytacji, może mieć kłopoty $\mathrm{w}$ interakcji z otoczeniem oraz $\mathrm{w}$ relacjach społecznych. Wprawdzie $\mathrm{w}$ społeczeństwach zachodnich powszechne jest przekonanie, że tłumienie złości jest szkodliwe w skutkach (zwłaszcza zdrowotnych), z drugiej strony - jeśli jawnie ją okazujemy - uważane jest to za reakcję niestosowną (Oatley i Jenkins, 2005). Psychologowie zdrowia potwierdzają jednak, że hamowanie gniewu może przynieść jednostce korzyści ze względu na poprawę relacji społecznych, jednakże ponoszone koszty są często dotkliwe dla zdrowia.

Warto zauważyć, że to nie samo przeżywanie złości, a raczej umiejętne, konstruktywne radzenie sobie z nią, ma rzeczywiste znaczenie dla prawidłowej adaptacji jednostki (Lewis i Haviland-Jones, 2005). Prawdą jest, że złość często poprzedza wystąpienie zachowań agresywnych, jednak nie dzieje się to zawsze (Franken, 2005). Dlatego tak ważne są zabiegi socjalizacyjne w celu rozwoju umiejętności regulowania tej emocji. Tym bardziej, że trudności radzenia sobie ze złością powodują rozwój chorób, a konstruktywne społecz- 
nie wyrażanie tej emocji wiąże się nie tylko $\mathrm{z}$ lepszym funkcjonowaniem jednostki w życiu codziennym, ale także z lepszymi osiągnięciami szkolnymi (Lewis i Haviland-Jones, 2005, s. 746).

Wracając do funkcji, jakie pełni gniew, należy zaznaczyć, że „część $\mathrm{z}$ nich jest typowa dla funkcji emocji w ogóle, jak np. funkcja sygnalizacji” (Żemojtel-Piotrowska i Piotrowski, 2012, s. 40). Psychologowie P. Ekman i R. J. Davidson (1998) wskazują na następujące funkcje emocji: (1) wzbudzanie zmian fizjologicznych, (2) gotowość do podjęcia określonych działań, (3) zmiany w aktywności poznawczej, (4) ułatwianie filogenetycznie adaptacyjnych reakcji, zwłaszcza w przypadku silnego natężenia emocji, (5) organizujące lub dezorganizujące wpływy emocji, (6) funkcje specyficzne dla danej emocji, (7) funkcje interpersonalne.

Badacze złości są zgodni, że emocja ta pełni przede wszystkim funkcje przystosowawcze. „Emocja ta organizuje i reguluje wewnętrzne procesy fizjologiczne i psychiczne związane z samoobroną i dominacją, a także z kontrolowaniem zachowań społecznych i interpersonalnych" (Lewis i Haviland-Jones, 2005, s. 746). Żemojtel-Piotrowska i Piotrowski podkreślają, że:

[w] rozważaniu możliwych funkcji złości należy przede wszystkim osobno uwzględnić funkcje związane z przeżywaniem złości i z jej wyrażaniem. Jedynie te ostatnie mają bezpośrednio charakter społeczny ze względu na komunikacyjne znaczenie ekspresji emocji i fakt, że dopiero wyrażenie złości wpływa na jej odbiorcę i szerszy kontekst społeczny. W przypadku złości jej odczuwanie prowadzi do dość silnych zmian fizjologicznych, a w sferze behawioralnej - do okazywania agresji (Żemojtel-Piotrowska, Piotrowski, 2012, s. 41).

Koncentrując się na funkcji złości związanej z jej przeżywaniem na plan pierwszy wysuwa się funkcja mobilizacyjna. Kiedy doświadczamy irytacji, pojawia się sytuacja rozbieżności między stanem pożądanym (celem) a rzeczywistym. Przeżywanie tej emocji jest związane z powstaniem pobudzenia fizjologicznego, a także z szeregiem specyficznych doznań somatycznych. Metaforycznie opisujemy ten stan używając określeń: „wrzenie”, „gotowanie się”, „buzowanie”. W takiej sytuacji naturalnie pojawia się tendencja do rozładowania nieprzyjemnego napięcia. Należy tutaj zauważyć, że nie zawsze w sytuacji przywoływanej rozbieżności pojawi się gniew. Alternatywnie możemy poczuć smutek, strach czy też poczucie krzywdy. Decyduje o tym nasza możliwość oceny poznawczej danej sytuacji. Dopiero gdy człowiek widzi możliwość zmiany, osiągnięcie określonego celu lub stanu, wówczas reaguje gniewem. Dodać należy, że złość może zostać ukierunkowana na konkretny obiekt, zwykle taki, który jednostka uznaje za przyczynę nieza- 
dowalającego stanu rzeczy. Może się jednak zdarzyć, że kierujemy gniew na osoby postronne, na których potencjalnie bezpiecznie można tę emocję „rozładować".

Irytujemy się też często w sytuacji, gdy doznajemy poczucia krzywdy, a doświadczanie krzywdy prowadzi zwykle do działań odwetowych (por. Gruszecka, 2003). Poczucie krzywdy również może być wyjściową do egzekwowania swoich praw i, w związku z tym, złość również tu pełni funkcję mobilizacyjną. Odwołujemy się wówczas do reguł wyznaczonych w danej grupie, społeczności, i uruchamiając tę funkcję staramy się poczucie krzywdy zamienić na poczucie sprawiedliwości.

Badania dowodzą, że ekspresja złości pełni funkcję instrumentalną (Fischer i Roseman, 2007) i prowadzi do zmiany stanu zewnętrznego - np. aby odstraszyć agresora, który zmusza osobę do podporządkowania, uległości, akceptacji poleceń. Okazuje się również z badań S. Hareliego, że

w przypadku skarg konsumenckich wyrażenie złości w trakcie składania reklamacji zwiększa szansę na uznanie jej za uzasadnioną wtedy, gdy istnieją wątpliwości co do słuszności skargi. Zwiększona wiarygodność niezadowolonego konsumenta zwiększa $\mathrm{z}$ kolei jego szansę na uznanie reklamacji, co ma trudny do przecenienia wymiar praktyczny (za: Żemojtel-Piotrowska, Piotrowski, 2012, s. 42).

Kolejną funkcją, jaką pełni wyrażanie gniewu, jest funkcja autoprezentacyjna. Osoba, która złości się w celu zastraszania, prezentuje się tym samym jako osoba silna i dominująca (Wojciszke, 2008). Możliwe jest to jednak w sytuacji, gdy jednostka ma silną pozycję w grupie i gniew okazuje w stosunku do osób podporządkowanych. Okazywanie złości w celach autoprezentacyjnych jest też sposobem na podkreślenie zachowań nonkonformistycznych i wyrażenie swojego stanowiska. Działania nonkonformistyczne pojawiają się często, gdy prezentuje się odmienne stanowisko w celu zwrócenia na siebie uwagi potencjalnej partnerki. Ma to związek z faktem, iż cechami cenionymi u mężczyzn przez kobiety są asertywność i dominacja (Hornsey, Majkut, Deborah i McKimmie, 2003).

Z perspektywy pedagogicznej najważniejsze wydają się społeczne funkcje złości. Skutki niewłaściwego wyrażania tej emocji mogą mieć bowiem charakter niepożądany i społecznie destruktywny. Wiąże się to głównie z dwoma zjawiskami towarzyszącymi złości - „chęcią odwetu na obiekcie wywołującym złość oraz kwestii rozładowania złości, najczęściej poprzez działania agresywne" (Żemojtel-Piotrowska i Piotrowski, 2012, s. 46). Jak podkreślają Oatley i Jenkins (2005), złość reguluje zachowania interpersonalne, ale jed- 
nocześnie emocja ta jest regulowana w kontekście interpersonalnym. Proces ten zachodzi w trakcie socjalizacji przez rodziców, nauczycieli, rówieśników i szersze środowisko społeczne. Co więcej, każda kultura dysponuje własnym repertuarem reguł okazywania złości. O ile mieszkańcy krajów południowej Europy mają większe społeczne przyzwolenie na wyrażanie irytacji, o tyle ludzie mieszkający w krajach skandynawskich nie epatują tym, co w rzeczywistości przeżywają.

Proces socjalizacji złości jest złożony i - co podkreślają badacze - dopiero zaczynamy go poznawać (Lewis i Haviland-Jones, 2005, s. 756). Tym niemniej badania już poczynione w tym obszarze wskazują, że techniki socjalizacyjne, mające na celu minimalizację negatywnych emocji (w tym złości), $\mathrm{w}$ połączeniu $\mathrm{z}$ treningiem emocjonalnym sprzyjają rozwojowi kompetencji społecznych i emocjonalnych. Nie można pominąć tu cech temperamentu człowieka, cech osobowościowych, jednakże działania na rzecz uczenia się radzenia sobie z irytacją zwiększają szansę (oprócz osiągnieć szkolnych czy zawodowych) na budowanie pozytywnych i trwałych związków międzyludzkich.

\section{Zakończenie}

Irytacja jest bez wątpienia jedną z częściej doświadczanych emocji w szkolnej rzeczywistości. Złoszczą się nauczyciele, uczniowie, rodzice, i każdy z podmiotów ma ważny - ze swojej perspektywy - powód. Czy w parze z przeżywaniem tej negatywnej emocji idzie również nauka umiejętności radzenia sobie $\mathrm{z}$ irytacją? Jak wskazałam wyżej, w sytuacji braku regulacji emocjonalnej możemy mieć trudności w kontaktach interpersonalnych. Ponadto, z uwagi na fakt, że irytacja pojawia się jako odpowiedź, reakcja na doświadczany ból, emocja ta wiąże się z zachowaniami agresywnymi, dominującymi, destruktywnymi. Zatem pojawiająca się złość w sytuacjach szkolnych raczej jest barierą, a nie szansą rozwoju, szczególnie rozwoju kompetencji emocjonalnych i społecznych.

W jednej z kluczowych pozycji literaturowych $\mathrm{z}$ dziedziny socjologii czytam: „Emocje są siłą motywującą, ponieważ nie tylko porządkują one subiektywne doświadczenia ludzi, ale również dodają energii ich reakcjom i nadają tym reakcjom kierunek" (Turner i Stets, 2009, s. 25). Jaki kierunek nadają działaniom ludzkim emocje irytacji - traktowane wymiennie z emocją złości czy gniewu? Badania dowodzą, że w przypadku gniewu występują u jednostki silne tendencje do działania mającego kogoś skrzywdzić. Dzieje się to częściej w sytuacji złości, niż w przypadku innych emocji, nawet tych uznawanych za negatywne (Berkowitz, 1999). Z perspektywy pedagogicznej ważne 
wydają się badania nad irytacją w przestrzeni szkolnej. Dokonanie analizy i interpretacji warunków, w jakich działają uczestnicy procesu edukacyjnego, mogłoby wyjaśnić przyczyny oraz cele i intencje osób okazujących złość.

Ken Kensey w kultowym już Locie nad KukutCzym GNiAzdem stwierdził, iż „[n]ic tak nie irytuje ludzi, którzy chcą ci obrzydzić życie, jak to, że zachowujesz się, jak gdybyś tego nie zauważał”. Tymczasem obojętność wobec doświadczanych i obserwowanych emocji może spowodować, co zauważył neurobiolog J. LeDoux, że obrócą się one przeciwko nam (LeDoux, 200o).

\section{BIBLIOGRAFIA}

Berkowitz, L. (1999). Anger. W: T. Dalgleish, M. J. Power (red.), Handbook of cognition and emotion. Chicester, England; New York: Wiley.

Davidson, J.R. (1999). O emocji, nastroju i innych pojęciach afektywnych. W: Ekman, P., Davidson, R.J. (red.). (1999). Natura emocji. Podstawowe zagadnienia. Przekł. B. Wojciszke. Gdańsk: GWP.

Ekman, P., Davidson, R.J. (red.). (1999). Natura emocji. Podstawowe zagadnienia. Przekł. B. Wojciszke. Gdańsk: GWP.

Fischer, A.H., Roseman, I.J. (2007). Beat them or ban them: The characteristics and social functions of anger and contempt. Journal of Personality and Social Psychology, t. 93(1), S. $103-115$.

Franken, R.E. (2005). Psychologia motywacji. Przekł. M. Przylipiak. Gdańsk: GWP.

Frijda, N. H. (1986). The emotions. Cambridge: Cambridge University Press.

Goffman, E. (2008). Człowiek w teatrze życia codziennego. Przekł. H. Datner-Śpiewak, P. Śpiewak. Warszawa: Wydawnictwo Aletheia.

Gruszecka, E. (2003). Strategie radzenia sobie z krzywdą: rodzaje, uwarunkowania, efektywność. W: B. Wojciszke, M. Plopa (red.), Osobowość a procesy psychiczne i zachowanie. Kraków: Oficyna Wydawnicza „Impuls”.

Hornsey, M.J., Majkut, L., Deborah, D.J., McKimmie, B.M. (2003). On being loud and proud: Non-conformity and counter-conformity to group norms. British Journal of Social Psycho$\log y$, t. 42, s. 319-335.

Hoschild, A. (2012). Praca emocjonalna, reguły odczuwania i struktura społeczna. W: M. Rajtar, J. Straczuk (red.), Emocje w kulturze. Warszawa: Wydawnictwa Uniwersytetu Warszawskiego, Narodowe Centrum Kultury.

Jarymowicz, M., Imbir, K. (2010). Próba taksonomii ludzkich emocji. Przegląd Psychologiczny, t. 53 , $\mathrm{nr} 4$, s. $439-461$.

Lazarus, R. S. (1991). Emotions and adaptations. New York: Oxford University Press.

LeDoux, J. E. (200o). Mózg emocjonalny. Przekł. A. Jankowski. Poznań: Media Rodzina.

Lewis, M., Haviland-Jones, J. M. (red.). (2005). Psychologia emocji. Gdańsk: Gdańskie Wydawnictwo Psychologiczne.

Łosiak, W. (2007). Psychologia emocji. Warszawa: Wydawnictwa Akademickie i Profesjonalne.

Markus R., Kitayama S., (1994). The cultural construction of self and emotion. W: S. Kitayama, R. Markus (red.), Emotion and culture. Washington, DC: American Psychological Association, s. 89-130.

Maruszewski, T., Doliński, D., Łukaszewski, W., Marszał-Wiśniewska, M. (20o8). Emocje i motywacja. W: J. Strelau, D. Doliński (red.), Psychologia. Podręcznik akademicki. Gdańsk: Gdańskie Wydawnictwo Psychologiczne.

Oatley, K., Jenkins, J.M. (2005). Zrozumieć emocje. Warszawa: Wydawnictwo Naukowe PWN. 
Plutchik, R. (1980). Emotion: A psychoevolutionary synthesis. New York: Harper and Row.

Russell, J. A. (1980). A circumplex model of affect. Journal of Personality and Social Psychology, t. 39(6), s. 1161-1178.

Russell, J. A. (1989). Measures of emotion. W: R. Plutchik, H. Kellerman (red.), Emotion. Theory, Research and Experiences (t. 4). Boston: Academic Press.

Salovey, P., Sluyter, D.J. (red.). (1999). Rozwój emocjonalny a inteligencja emocjonalna. Poznań: Dom Wydawniczy Rebis.

Stanisławski, K. (2014). Wpływ stresu na emocje i motywacje... Badania quasi-eksperymentalne. W: E. Topolewska, E. Skimina, S. Skrzek (red.), Młoda Psychologia (t. 2). [Stare Kościeliska]: Wydawnictwo Liberi Libri.

Strelau, J., Doliński, D. (red.). (2008). Psychologia. Podręcznik akademicki. Gdańsk: Gdańskie Wydawnictwo Psychologiczne.

Szymczak, M. (red.). (1978). Słownik języka polskiego (t. 1). Warszawa: PWN.

Turner, J. H., Stets, J. E. (2009). Socjologia emocji. Warszawa: Wydawnictwo Naukowe PWN.

Wojciszke, B. (2008). Człowiek wśród ludzi. Warszawa: Wydawnictwo Scholar.

Yik, M. M. (2009). Studying affect among the Chinese: The circular way. Journal of Personality Assessment, t. 91(5), s. 416-428.

Żemojtel-Piotrowska, M., Piotrowski, J. (2012). Kiedy złość motywuje? Społeczne funkcje wyrażania złości. W: B. Bereza (red.), Oblicza złości. Perspektywa psychologów, psychiatrów i psychoterapeutów. Warszawa: Wydawnictwo DIFIN.

\section{SUMMARY}

\section{About irritation without irritation}

Emotions of different signs-both positive and negative-are not at all something strange or abnormal, on the contrary-they are important and necessary in our lives. What is more, every day we experience emotions, under which we make decisions, we act in one way or another. The author of the article tries to analyze the category of "irritation". Annoyance is an emotion of exceptional public importance, hence the considerations presented in the text refer to the achievements of the social sciences (psychology, sociology). The text has a review character. The basic classifications of emotions, functioning in the literature, have been presented in the text, and on this background, the emotion of annoyance (often referred to as anger or wrath) has been located. The paper presents also the causes and mechanisms of irritation appearance. The attention has been also drawn to the course of this emotion and its social functions.

KEY WORDS: irritation, anger, wrath, mechanisms of anger appearance, social functions of anger. 